Research article

Open Access

\title{
Plasma carotenoids, retinol, and tocopherols and postmenopausal breast cancer risk in the Multiethnic Cohort Study: a nested case-control study
} Meira Epplein ${ }^{1}$, Yurii B Shvetsov'1, Lynne R Wilkens' ${ }^{1}$, Adrian A Franke1, Robert V Cooney ${ }^{1}$, Loïc Le Marchand ${ }^{1}$, Brian E Henderson ${ }^{2}$, Laurence N Kolonel ${ }^{1}$ and Marc T Goodman ${ }^{1}$

\author{
${ }^{1}$ Epidemiology Program, Cancer Research Center of Hawaii, University of Hawaii, 1236 Lauhala Street, Honolulu, HI 96813, USA \\ 2Department of Preventive Medicine, Keck School of Medicine, University of Southern California, 1441 Eastlake Avenue, Los Angeles, CA 90089, \\ USA \\ Corresponding author: Meira Epplein, mepplein@crch.hawaii.edu
}

Received: 2 Jun 2009 Revisions requested: 29 Jun 2009 Revisions received: 14 Jul 2009 Accepted: 20 Jul 2009 Published: 20 Jul 2009

Breast Cancer Research 2009, 11:R49 (doi:10.1186/bcr2338)

This article is online at: http://breast-cancer-research.com/content/11/4/R49

(c) 2009 Epplein et al.; licensee BioMed Central Ltd.

This is an open access article distributed under the terms of the Creative Commons Attribution License (http://creativecommons.org/licenses/by/2.0), which permits unrestricted use, distribution, and reproduction in any medium, provided the original work is properly cited.

\begin{abstract}
Introduction Assessments by the handful of prospective studies of the association of serum antioxidants and breast cancer risk have yielded inconsistent results. This multiethnic nested case-control study sought to examine the association of plasma carotenoids, retinol, and tocopherols with postmenopausal breast cancer risk.

Methods From the biospecimen subcohort of the Multiethnic Cohort Study, 286 incident postmenopausal breast cancer cases were matched to 535 controls on age, sex, ethnicity, study location (Hawaii or California), smoking status, date/time of collection and hours of fasting. We measured prediagnostic circulating levels of individual carotenoids, retinol, and tocopherols. Conditional logistic regression was used to compute odds ratios and 95\% confidence intervals.
\end{abstract}

Results Women with breast cancer tended to have lower levels of plasma carotenoids and tocopherols than matched controls, but the differences were not large or statistically significant and the trends were not monotonic. No association was seen with retinol. A sensitivity analysis excluding cases diagnosed within 1 year after blood draw did not alter the findings.

Conclusions The lack of significant associations in this multiethnic population is consistent with previously observed results from less racially-diverse cohorts and serves as further evidence against a causal link between plasma micronutrient concentrations and postmenopausal breast cancer risk.

\section{Introduction}

An expert panel recently concluded that an inverse association of carotenoids with breast cancer risk is possible because of their antioxidant properties [1], but methodological problems and the lack of human studies presently limit scientific judgment on the relationship [2]. Assessments of the association of dietary carotenoids and tocopherols with breast cancer risk from cohort studies have yielded inconsistent results; and only a handful of prospective studies have investigated the relation of risk to serum antioxidants, also with mixed results $[3,4]$. In the present nested case-control study, we tested the hypothesis that plasma concentrations of carotenoids, retinol, and tocopherols are inversely related to breast cancer risk.

\section{Materials and methods}

The study population included participants in the biospecimen subcohort of the Multiethnic Cohort Study [5,6]. Briefly, more than 215,000 African American, Caucasian, Japanese American, Latino, and Native Hawaiian adults, aged 45 to 75 years in 1993, completed a 26-page baseline questionnaire between 1993 and 1996 in Hawaii and in Los Angeles. A biospecimen subcohort was established among Multiethnic Cohort Study participants, primarily from 2001 to 2006, including 36,458 women who completed a short telephone questionnaire and provided blood ( 94\% fasting) and overnight or first-morning urine.

Micronutrient analyses included prediagnostic blood from 334 postmenopausal women with breast cancer identified through 
linkage with Hawaii and California cancer registries through 2006. Two control individuals for each case were randomly chosen from the women in the biospecimen subcohort who were alive and free of breast cancer at the age of the case's diagnosis, and who matched the case on birth year ( \pm 1 year), race/ethnicity, location (Hawaii or California), date $( \pm 6$ months) and time ( \pm 2 hours) of blood draw, fasting hours (8 to $<10$ hours and $10+$ hours), and hormone therapy use (current versus not current). Plasma concentrations of carotenoids, retinoids, and tocopherols were determined by highpressure liquid chromatography with photodiode array detection from our earlier protocol $[7,8]$, with slight modifications
[6]. The median time from blood draw to date of diagnosis was 1 year and 5 months, with the middle $50 \%$ of subjects having follow-up time in the range of 8 months to 2.5 years.

The Multiethnic Cohort Study and the nested case-control study from the biospecimen subcohort were approved by the Institutional Review Boards of the University of Hawaii and the University of Southern California. Cohort participants provided informed consent for both studies.

Conditional logistic regression, with matched sets as strata, was used to compute odds ratios and 95\% confidence inter-

\section{Table 1}

\section{Characteristics of breast cancer cases and controls}

\begin{tabular}{|c|c|c|}
\hline General characteristic & Cases $(n=286)$ & Controls $(n=535)$ \\
\hline Age at blood draw (years) & $66.0(8.1)$ & $66.0(8.0)$ \\
\hline Fasting hours prior to blood drawa & $13.1(1.9)$ & $13.0(1.8)$ \\
\hline Current hormone therapy use ${ }^{a}$ & $99(35 \%)$ & $185(35 \%)$ \\
\hline \multicolumn{3}{|l|}{ Ethnicitya } \\
\hline African American & $35(12 \%)$ & $65(12 \%)$ \\
\hline Caucasian & $59(21 \%)$ & $111(21 \%)$ \\
\hline Japanese American & $116(40 \%)$ & $213(40 \%)$ \\
\hline Latina & $45(16 \%)$ & $86(16 \%)$ \\
\hline Native Hawaiian & $31(11 \%)$ & $60(11 \%)$ \\
\hline High school education or less & $97(34 \%)$ & $189(35 \%)$ \\
\hline Body mass index $\left(\mathrm{kg} / \mathrm{m}^{2}\right)$ & $25.6(4.9)$ & $25.4(5.4)$ \\
\hline Nulliparous & $35(12 \%)$ & $58(11 \%)$ \\
\hline Number of full-term pregnancies & $2.7(1.8)$ & $2.8(1.8)$ \\
\hline Age at first childbirth & $23.8(4.6)$ & $23.5(4.5)$ \\
\hline Age at menarche & $13.0(1.6)$ & $13.1(1.6)$ \\
\hline Age at natural menopause & $49.1(5.1)$ & $49.5(4.7)$ \\
\hline \multicolumn{3}{|l|}{ Smoking status } \\
\hline Never & $159(56 \%)$ & $334(63 \%)$ \\
\hline Former & $90(32 \%)$ & $146(27 \%)$ \\
\hline Current & $35(12 \%)$ & $52(10 \%)$ \\
\hline Pack-years of smoking & $6.2(11.2)$ & $5.4(11.0)$ \\
\hline Mother or sister with breast cancer & $31(11 \%)$ & $68(13 \%)$ \\
\hline \multicolumn{3}{|l|}{ Alcohol use } \\
\hline Never & $170(60 \%)$ & $347(65 \%)$ \\
\hline Ever, below users' median $(<3.4 \mathrm{~g} /$ day $)$ & $58(20 \%)$ & $95(18 \%)$ \\
\hline Ever, above users' median (> $>.4 \mathrm{~g} /$ day) & $58(20 \%)$ & $93(17 \%)$ \\
\hline Hours in moderate or vigorous physical activity per day & $1.2(1.3)$ & $1.2(1.3)$ \\
\hline
\end{tabular}

Data presented as mean \pm standard deviation or $n(\%)$. Matching variable. 
Table 2

\begin{tabular}{|c|c|c|c|}
\hline Antioxidant (ng/ml) & Number of cases/controls ${ }^{b}$ & Odds ratioc & $95 \%$ confidence interva \\
\hline \multicolumn{4}{|l|}{ Total carotenoids } \\
\hline$\leq 1,129.4$ & $76 / 129$ & 1.00 & \\
\hline $1,129.5$ to $1,510.2$ & $71 / 135$ & 0.88 & 0.58 to 1.32 \\
\hline $1,510.3$ to $1,953.0$ & $73 / 132$ & 0.90 & 0.59 to 1.37 \\
\hline \multirow[t]{2}{*}{$\geq 1,953.1$} & $66 / 139$ & 0.80 & 0.51 to 1.26 \\
\hline & & $\left(P_{\text {trend }}=0.39\right)$ & \\
\hline \multicolumn{4}{|l|}{ Total carotenes } \\
\hline$\leq 231.7$ & $79 / 126$ & 1.00 & \\
\hline 231.8 to 373.5 & $66 / 139$ & 0.75 & 0.49 to 1.14 \\
\hline 373.6 to 569.5 & $82 / 123$ & 0.99 & 0.64 to 1.52 \\
\hline \multirow[t]{2}{*}{$\geq 569.6$} & $59 / 147$ & 0.61 & 0.38 to 0.97 \\
\hline & & $\left(P_{\text {trend }}=0.08\right)$ & \\
\hline \multicolumn{4}{|l|}{$\alpha$-Carotene } \\
\hline$\leq 42.0$ & $73 / 132$ & 1.00 & \\
\hline 42.1 to 67.5 & $70 / 135$ & 0.95 & 0.62 to 1.45 \\
\hline 67.6 to 101.7 & $75 / 131$ & 1.06 & 0.69 to 1.64 \\
\hline \multirow[t]{2}{*}{$\geq 101.8$} & $68 / 137$ & 0.88 & 0.56 to 1.39 \\
\hline & & $\left(P_{\text {trend }}=0.64\right)$ & \\
\hline \multicolumn{4}{|l|}{$\beta$-Carotene } \\
\hline$\leq 180.4$ & $79 / 127$ & 1.00 & \\
\hline 180.5 to 301.9 & $64 / 140$ & 0.74 & 0.49 to 1.13 \\
\hline 302.0 to 460.8 & $79 / 126$ & 0.97 & 0.63 to 1.48 \\
\hline \multirow[t]{2}{*}{$\geq 460.9$} & $64 / 142$ & 0.73 & 0.46 to 1.15 \\
\hline & & $\left(P_{\text {trend }}=0.30\right)$ & \\
\hline \multicolumn{4}{|l|}{ trans- $\beta$-Carotene } \\
\hline$\leq 168.8$ & $79 / 126$ & 1.00 & \\
\hline 168.9 to 283.7 & $65 / 140$ & 0.76 & 0.50 to 1.14 \\
\hline 283.8 to 432.5 & $76 / 129$ & 0.91 & 0.59 to 1.40 \\
\hline \multirow[t]{2}{*}{$\geq 432.6$} & $66 / 140$ & 0.76 & 0.49 to 1.19 \\
\hline & & $\left(P_{\text {trend }}=0.37\right)$ & \\
\hline \multicolumn{4}{|l|}{ cis- $\beta$-Carotene } \\
\hline$\leq 11.9$ & $78 / 128$ & 1.00 & \\
\hline 12.0 to 19.5 & $72 / 133$ & 0.89 & 0.59 to 1.33 \\
\hline 19.6 to 30.5 & $75 / 129$ & 0.91 & 0.60 to 1.38 \\
\hline \multirow[t]{2}{*}{$\geq 30.6$} & $61 / 145$ & 0.68 & 0.43 to 1.07 \\
\hline & & $\left(P_{\text {trend }}=0.10\right)$ & \\
\hline \multicolumn{4}{|l|}{ Lycopene } \\
\hline$\leq 218.7$ & 73/133 & 1.00 & \\
\hline 218.8 to 292.2 & $75 / 130$ & 1.04 & 0.68 to 1.58 \\
\hline 292.3 to 391.7 & $70 / 135$ & 0.91 & 0.06 to 1.37 \\
\hline \multirow[t]{2}{*}{$\geq 391.8$} & $68 / 137$ & 0.88 & 0.57 to 1.38 \\
\hline & & $\left(P_{\text {trend }}=0.50\right)$ & \\
\hline
\end{tabular}


Breast Cancer Research Vol 11 No 4 Epplein et al.

Table 2 (Continued)

Risk of breast cancer across quartiles of plasma carotenoids, tocopherols, and retinola

\begin{tabular}{|c|c|c|c|}
\hline \multicolumn{4}{|c|}{ trans-Lutein/zeaxanthin } \\
\hline$\leq 186.8$ & $77 / 129$ & 1.00 & \\
\hline 186.9 to 246.5 & $70 / 135$ & 0.92 & 0.60 to 1.41 \\
\hline 246.6 to 312.5 & $70 / 135$ & 0.91 & 0.59 to 1.41 \\
\hline \multirow[t]{2}{*}{$\geq 312.6$} & $69 / 136$ & 0.87 & 0.57 to 1.34 \\
\hline & & $\left(P_{\text {trend }}\right)$ & \\
\hline \multicolumn{4}{|l|}{ trans-Lutein } \\
\hline$\leq 129.7$ & $79 / 126$ & 1.00 & \\
\hline 129.8 to 174.4 & $63 / 143$ & 0.74 & 0.48 to 1.12 \\
\hline 174.5 to 223.4 & $74 / 131$ & 0.94 & 0.62 to 1.44 \\
\hline \multirow[t]{2}{*}{$\geq 223.5$} & $70 / 135$ & 0.85 & 0.55 to 1.29 \\
\hline & & $\left(P_{\text {trend }}\right)$ & \\
\hline \multicolumn{4}{|l|}{ trans-Zeaxanthin } \\
\hline$\leq 53.6$ & $71 / 134$ & 1.00 & \\
\hline 53.7 to 70.7 & $80 / 126$ & 1.17 & 0.78 to 1.77 \\
\hline 70.8 to 92.2 & $69 / 135$ & 0.95 & 0.60 to 1.50 \\
\hline \multirow[t]{2}{*}{$\geq 92.3$} & $66 / 140$ & 0.88 & 0.56 to 1.39 \\
\hline & & $\left(P_{\text {trend }}\right)$ & \\
\hline \multicolumn{4}{|c|}{ cis-Lutein/zeaxanthin } \\
\hline$\leq 90.8$ & $79 / 127$ & 1.00 & \\
\hline 90.9 to 111.7 & $63 / 142$ & 0.70 & 0.46 to 1.06 \\
\hline 111.8 to 137.8 & $77 / 128$ & 0.90 & 0.59 to 1.37 \\
\hline \multirow[t]{2}{*}{$\geq 137.9$} & $67 / 138$ & 0.75 & 0.48 to 1.16 \\
\hline & & $\left(P_{\text {trend }}\right)$ & \\
\hline \multicolumn{4}{|l|}{ trans-Anhydrolutein } \\
\hline$\leq 40.0$ & $76 / 129$ & 1.00 & \\
\hline 40.1 to 54.0 & $71 / 135$ & 0.88 & 0.57 to 1.36 \\
\hline 54.1 to 73.6 & $74 / 131$ & 0.94 & 0.62 to 1.43 \\
\hline \multirow[t]{2}{*}{$\geq 73.7$} & $65 / 140$ & 0.78 & 0.50 to 1.22 \\
\hline & & $\left(P_{\text {trend }}\right)$ & \\
\hline \multicolumn{4}{|l|}{ cis-Anhydrolutein } \\
\hline$\leq 32.9$ & $67 / 138$ & 1.00 & \\
\hline 33.0 to 44.5 & $73 / 132$ & 1.20 & 0.78 to 1.84 \\
\hline 44.6 to 57.7 & 73/133 & 1.21 & 0.78 to 1.87 \\
\hline \multirow[t]{2}{*}{$\geq 57.8$} & $73 / 132$ & 1.21 & 0.77 to 1.91 \\
\hline & & $\left(P_{\text {trend }}\right)$ & \\
\hline \multicolumn{4}{|l|}{$\alpha$-Cryptoxanthin } \\
\hline$\leq 30.8$ & $67 / 138$ & 1.00 & \\
\hline 30.9 to 38.9 & $79 / 126$ & 1.28 & 0.84 to 1.96 \\
\hline 39.0 to 49.5 & $71 / 135$ & 1.10 & 0.72 to 1.68 \\
\hline$\geq 49.6$ & $69 / 136$ & 1.08 & 0.68 to 1.70 \\
\hline
\end{tabular}


Risk of breast cancer across quartiles of plasma carotenoids, tocopherols, and retinola

\begin{tabular}{|c|c|c|c|}
\hline & & $\left(P_{\text {trend }}\right.$ & \\
\hline trans- $\beta$-Cryptoxanthin & & & \\
\hline$\leq 93.8$ & $69 / 137$ & 1.00 & \\
\hline 93.9 to 169.0 & $77 / 127$ & 1.22 & 0.81 to 1.85 \\
\hline 169.1 to 293.7 & $61 / 145$ & 0.85 & 0.55 to 1.33 \\
\hline$\geq 293.8$ & $79 / 126$ & 1.36 & 0.85 to 2.16 \\
\hline & & $\left(P_{\text {trend }}\right.$ & \\
\hline cis- $\beta$-Cryptoxanthin & & & \\
\hline$\leq 36.4$ & $69 / 136$ & 1.00 & \\
\hline 36.5 to 53.9 & $72 / 133$ & 1.08 & 0.71 to 1.64 \\
\hline 54.0 to 87.0 & $67 / 139$ & 0.96 & 0.62 to 1.50 \\
\hline$\geq 87.1$ & $78 / 127$ & 1.27 & 0.81 to 1.99 \\
\hline & & $\left(P_{\text {trend }}\right.$ & \\
\hline Retinol & & & \\
\hline$\leq 842.6$ & $66 / 139$ & 1.00 & \\
\hline 842.7 to 997.9 & $76 / 130$ & 1.29 & 0.85 to 1.95 \\
\hline 998.0 to $1,187.9$ & $72 / 133$ & 1.18 & 0.75 to 1.86 \\
\hline$\geq 1,188.0$ & $72 / 133$ & 1.13 & 0.73 to 1.76 \\
\hline & & $\left(P_{\text {trend }}\right.$ & \\
\hline Total tocopherols & & & \\
\hline$\leq 14,413.3$ & $78 / 128$ & 1.00 & \\
\hline $14,413.4$ to $17,909.5$ & $73 / 132$ & 0.95 & 0.63 to 1.42 \\
\hline $17,909.6$ to $23,282.3$ & $63 / 142$ & 0.74 & 0.48 to 1.14 \\
\hline$\geq 23,282.4$ & $72 / 133$ & 0.86 & 0.56 to 1.31 \\
\hline & & $\left(P_{\text {trend }}\right.$ & \\
\hline$\alpha$-Tocopherol & & & \\
\hline$\leq 11,828.1$ & $80 / 125$ & 1.00 & \\
\hline $11,828.2$ to $16,021.0$ & $68 / 138$ & 0.79 & 0.52 to 1.20 \\
\hline $16,021.1$ to $21,829.8$ & $66 / 138$ & 0.75 & 0.49 to 1.16 \\
\hline$\geq 21,829.9$ & $72 / 134$ & 0.80 & 0.52 to 1.24 \\
\hline & & $\left(P_{\text {trend }}\right.$ & \\
\hline$\beta+\gamma$-Tocopherol & & & \\
\hline$\leq 619.0$ & $64 / 142$ & 1.00 & \\
\hline 619.1 to $1,243.2$ & $71 / 134$ & 1.24 & 0.80 to 1.91 \\
\hline $1,243.3$ to $2,175.2$ & $76 / 129$ & 1.32 & 0.87 to 2.02 \\
\hline$\geq 2,175.3$ & $75 / 130$ & 1.40 & 0.86 to 2.27 \\
\hline & & $\left(P_{\text {trend }}\right.$ & \\
\hline$\delta$-Tocopherol & & & \\
\hline$\leq 190.1$ & $71 / 134$ & 1.00 & \\
\hline 190.2 to 257.1 & $60 / 145$ & 0.78 & 0.48 to 1.25 \\
\hline 257.2 to 339.2 & $85 / 121$ & 1.35 & 0.82 to 2.22 \\
\hline$\geq 339.3$ & $70 / 135$ & 0.99 & 0.58 to 1.70 \\
\hline & & $\left(P_{\text {trend }}\right.$ & \\
\hline
\end{tabular}

aLinear dose-response in the logit of risk was tested by a Wald test for each biomarker modeled as a trend variable assigned the median value of the appropriate category. ${ }^{b}$ Controls $(n=535)$ were women matched to cases $(n=286)$ on geographic area, ethnicity, year of birth, date and time of specimen collection, fasting status, and hormone therapy use. ${ }^{\circ}$ Adjusted by conditional logistic regression with matched sets as strata, with additional adjustment for age at blood draw and fasting hours prior to blood draw (as continuous variables), as well as body mass index, alcohol use, age at menarche, age at menopause, age at first birth, and number of full-term pregnancies. 
vals. Biomarker variables were categorized into quartiles based on the distribution of cases and controls in order to optimize the distribution of cases and controls in each of the strata of interest so that none of the cells had overly small numbers of subjects. A trend variable for each biomarker was created by assigning the median value of the appropriate category. Aside from matching variables, the full models were adjusted for the following established breast cancer risk factors [9]: body mass index, alcohol use, age at first birth, number of fullterm pregnancies, age at menarche, and age at menopause. Interactions with smoking status, race/ethnicity, and body mass index were assessed, and a separate model was considered excluding subjects who were diagnosed within 1 year after blood draw. All analyses were conducted using SAS software (version 9.1; SAS Institute, Cary, NC, USA).

\section{Results}

Only matched sets that included one case and at least one control with no missing data on plasma micronutrients or any of the adjustment variables were retained in these analyses, resulting in a study population of 286 cases and 535 controls. Cases were similar to controls for most baseline characteristics, except that cases were more likely to be former or current smokers and ever drinkers than controls (Table 1).

Women with breast cancer tended to have lower levels of plasma carotenoids and tocopherols than matched controls, but the differences were not large or statistically significant and the trends were not monotonic (Table 2). When stratified by smoking status, ever smokers, but not never smokers, in the highest quartile compared with the lowest quartile of total carotenoid levels had a significantly decreased risk of breast cancer (odds ratio $=0.29,95 \%$ confidence interval $=0.10$ to 0.85 for ever smokers; odds ratio $=1.19,95 \%$ confidence interval $=0.62$ to 2.27 for never smokers). No evidence was found, however, for an interaction $\left(P_{\text {interaction }}=0.17\right)$ between smoking and circulating carotenoids on risk; nor was there evidence that other variables modified the micronutrient-breast cancer risk association. A sensitivity analysis excluding cases diagnosed within 1 year after blood draw did not alter the findings.

\section{Discussion}

The present case-control study - nested within a large prospective cohort - does not support an association of plasma carotenoids, retinol, or tocopherols with postmenopausal breast cancer risk.

The observation of a lack of an association between breast cancer risk and plasma tocopherols and retinol mirrors what has been seen in recent prospective studies [4,10-13]. Additionally, a recent clinical trial did not observe any change in risk of breast cancer among women assigned to receive vitamin $\mathrm{E}$ supplements [14]. The carotenoid findings, too, are consistent with the null results from the Shanghai Women's Health Study
[4]. Five other recent large ( $>100$ cases) prospective studies of plasma antioxidants and risk of breast cancer, however, did report some significant associations with carotenoids. Four of the five studies found breast cancer risk to be inversely associated with $\alpha$-carotene, $\beta$-carotene, and/or total carotenoids $[11-13,15]$; two of the five studies observed an inverse association with lycopene $[10,13]$, and one of these also observed an inverse association with $\gamma$-tocopherol [13].

The suggested inverse association of carotenoids with breast cancer risk limited to ever smokers, observed in our study, is biologically plausible as cigarette smoke contributes to oxidative stress and a reduction in plasma carotenoids [16]. Accordingly, smokers stand to benefit more from the antioxidant properties of carotenoids. Among the two previous studies that examined the breast cancer-circulating carotenoid association by smoking status, however, one reported that the inverse association of $\alpha$-carotene with breast cancer risk may be limited to never smokers and past smokers $\left(P_{\text {interaction }}=\right.$ $0.10)$ [12]; the other study found no evidence for a smokingcirculating carotenoid interaction on breast cancer risk after restricting the analysis to women who were diagnosed with breast cancer at least 2 years after blood draw [10]. Two recent studies of dietary antioxidants and breast cancer risk from the Collaborative Breast Cancer Study and the Nurses' Health Study, however, found decreases in risk with increases in carotenoids among current smokers only, similar to the present study $[17,18]$.

Limitations to the current study include the use of only one measure to assess exposure, the possibility that the exposure was not assessed during the relevant time period, a relatively short follow-up time, and the inability to stratify by tumor characteristics. These limitations would most probably bias the risk estimates toward the null. We were also unable to assess whether the associations we observed with carotenoids were due to factors other than a high consumption of fruits and vegetables that are also related to a healthy lifestyle. We did, however, adjust for maximum years of education obtained, and saw no significant changes in the results. The study is strengthened by its multiethnic population, which had similarly high levels of antioxidants, including carotenoids, as those reported in the Nurses' Health Study [12]. These levels are higher than those reported in the majority of the previous studies $[10,11,13,15]$. The difference in antioxidant levels could, however, be due to laboratory variability and/or due to the diet of our population.

\section{Conclusions}

The lack of significant associations in the present multiethnic population is consistent with previously observed results from less racially-diverse cohorts and serves as further evidence against a causal link between plasma micronutrient concentrations and postmenopausal breast cancer risk. 


\section{Competing interests}

The authors declare that they have no competing interests.

\section{Authors' contributions}

All of the authors made substantial contributions to the study concept and design or analysis and interpretation of the data. Specifically, ME designed the analysis, analyzed the results, and was the primary author of every section of the text. YBS aided in the design of the analysis and performed much of the initial statistical analyses. LRW helped to design the study's analytic strategy and prepare the Materials and methods section of the text. AAF and RVC carried out the micronutrient assays. LLM, BEH, and LNK were instrumental in the design of the study, and commented on and approved the manuscript. MTG originally conceived of the study and helped to draft the manuscript.

\section{Acknowledgements}

Financial support for the present study was received from the National Cancer Institute Grants P01 CA33619, R37 CA54281 and P30 CA71789, and Contracts N01-PC-35137 and N01-PC-35139. ME was supported by a postdoctoral fellowship on Grant R25 CA 90956. The funding bodies played no role in the study design; in collection, analysis, or interpretation of the data; in writing of the manuscript; or in the decision to submit the manuscript for publication.

\section{References}

1. Krinsky NI, Johnson EJ: Carotenoid actions and their relation to health and disease. Mol Aspects Med 2005, 26:459-516.

2. World Cancer Research Fund/American Institute for Cancer Research: Food, Nutrition, Physical Activity, and the Prevention of Cancer: A Global Perspective Washington, DC: AICR; 2007.

3. Michels KB, Mohllajee AP, Roset-Bahmanyar E, Beehler GP, Moysich KB: Diet and breast cancer: a review of the prospective observational studies. Cancer 2007, 109:2712-2749.

4. Dorjgochoo T, Gao YT, Chow WH, Shu XO, Li H, Yang G, Cai Q, Rothman N, Cai H, Franke AA, Zheng W, Dai Q: Plasma carotenoids, tocopherols, retinol and breast cancer risk: results from the Shanghai Women Health Study (SWHS). Breast Cancer Res Treat 2008 in press.

5. Kolonel LN, Henderson BE, Hankin JH, Nomura AM, Wilkens LR, Pike MC, Stram DO, Monroe KR, Earle ME, Nagamine FS: A multiethnic cohort in Hawaii and Los Angeles: baseline characteristics. Am J Epidemiol 2000, 151:346-357.

6. Epplein M, Wilkens LR, Tiirikainen M, Dyba M, Chung FL, Goodman MT, Murphy SP, Henderson BE, Kolonel LN, Le Marchand L: Urinary isothiocyanates; glutathione S-transferase M1, T1, and P1 polymorphisms; and risk of colorectal cancer: the Multiethnic Cohort Study. Cancer Epidemiol Biomarkers Prev 2009, 18:314-320.

7. Cooney RV, Franke AA, Hankin JH, Custer LJ, Wilkens LR, Harwood PJ, Le Marchand L: Seasonal variations in plasma micronutrients and antioxidants. Cancer Epidemiol Biomarkers Prev 1995, 4:207-215.

8. Franke AA, Custer LJ, Cooney RV: Synthetic carotenoids as internal standards for plasma micronutrient analyses by highperformance liquid chromatography. J Chromatogr 1993, 614:43-57.

9. Pike MC, Kolonel LN, Henderson BE, Wilkens LR, Hankin JH, Feigelson HS, Wan PC, Stram DO, Nomura AM: Breast cancer in a multiethnic cohort in Hawaii and Los Angeles: risk factoradjusted incidence in Japanese equals and in Hawaiians exceeds that in whites. Cancer Epidemiol Biomarkers Prev 2002, 11:795-800.

10. Dorgan JF, Sowell A, Swanson CA, Potischman N, Miller R, Schussler N, Stephenson HE Jr: Relationships of serum carotenoids, retinol, $\alpha$-tocopherol, and selenium with breast cancer risk: results from a prospective study in Columbia, Missouri (United States). Cancer Causes Control 1998, 9:89-97.

11. Sato R, Helzlsouer KJ, Alberg AJ, Hoffman SC, Norkus EP, Comstock GW: Prospective study of carotenoids, tocopherols, and retinoid concentrations and the risk of breast cancer. Cancer Epidemiol Biomarkers Prev 2002, 11:451-457.

12. Tamimi RM, Hankinson SE, Campos $H$, Spiegelman D, Zhang $S$, Colditz GA, Willett WC, Hunter DJ: Plasma carotenoids, retinol, and tocopherols and risk of breast cancer. Am J Epidemiol 2005, 161:153-160.

13. Kabat GC, Kim M, Adams-Campbell LL, Caan BJ, Chlebowski RT, Neuhouser ML, Shikany JM, Rohan TE: Longitudinal study of serum carotenoid, retinol, and tocopherol concentrations in relation to breast cancer risk among postmenopausal women. Am J Clin Nutr 2009, 90:162-169.

14. Lee IM, Cook NR, Gaziano JM, Gordon D, Ridker PM, Manson JE, Hennekens $\mathrm{CH}$, Buring JE: Vitamin $\mathrm{E}$ in the primary prevention of cardiovascular disease and cancer: the Women's Health Study: a randomized controlled trial. JAMA 2005, 294:56-65.

15. Toniolo P, Van Kappel AL, Akhmedkhanov A, Ferrari P, Kato I, Shore RE, Riboli E: Serum carotenoids and breast cancer. $\mathrm{Am}$ $J$ Epidemiol 2001, 153:1142-1147.

16. Handelman GJ, Packer L, Cross CE: Destruction of tocopherols, carotenoids, and retinol in human plasma by cigarette smoke. Am J Clin Nutr 1996, 63:559-565.

17. Cho E, Spiegelman D, Hunter DJ, Chen WY, Zhang SM, Colditz GA, Willett WC: Premenopausal intakes of vitamins A, C, and $\mathrm{E}$, folate, and carotenoids, and risk of breast cancer. Cancer Epidemiol Biomarkers Prev 2003, 12:713-720.

18. Mignone LI, Giovannucci E, Newcomb PA, Titus-Ernstoff L, Trentham-Dietz A, Hampton JM, Willett WC, Egan KM: Dietary carotenoids and the risk of invasive breast cancer. Int $\mathrm{J}$ Cancer 2009, 124:2929-2937. 